\title{
КОРУПЦІЯ: ГОЛОВНА ПРИЧИНА БІДНОСТІ ТА ПІДРИВУ ОСНОВ ДЕМОКРАТІЇ УКРӒ̈̈И
}

Пьохов В. М., Шевчук В. В.

У cmammi розкриті взаємопов'язані поняття «бідність» $i$ «корупція» в умовах демократії по-українськи, проаналізовано їх структуру, рівень та динаміку. Здійснено порівняльний аналіз з деякими країнами Євросоюзу, іншими цивілізованими державами. Запропоновані заходи чесного розподілу природних ресурсів і прибутків від користування багатствами країни, а також поступового вирішення питань із запобігання і протидії як бідності, так і корупції.

Ключові слова: бідність, корупція, елітна корупція, мафія, демократія, життєвий рівень, прожитковий мінімум.

В статье раскрыты взаимосвязанные понятия «бедность» и «коррупция» в условиях демократии по-украински, проанализированы их структура, уровень и дина мика. Осуществлён сравнительный анализ с некоторыми странами Евросоюза, другими цивилизованными государ ствами. Предложены меры честного распределения природных ресурсов и доходов от использования богатств страны, а также постепенного решения вопросов по пре дотвращению и противодействию как бедности, так и коррупции.

Ключевые слова: бедность, коррупция, элитная коррупция, мафия, демократия, уровень жизни, прожиточный минимум.

The article describes the interconnected notions of "poverty" and "corruption" in a democracy in Ukrainian, analyzes its structure, level, and dynamics.

The essence of our so-called legal and democratic country, which exists first of all for the power-holders, is defined, and for the common people there are only slogans by which the statepower oligarchy, blatantly violating the norms of morality, democracy and the Constitution, covers its corrupt actions: constantly increasing tariffs on energy carriers; at the same time rising prices for social food and essentials; the privileges of Chernobyl victims, veterans of the Ministry of Defense, the State Emergency Service, the Ministry of Internal Affairs and the disabled are being abolished.

The ways of systematization of the whole antisocial pyramid of the destruction of the people of Ukraine - the genocide of the 21st century are investigated.

The place and role of corrupt officials in the historical aspect as well as in the modern life are determined, a comparative analysis with some EU countries and other civilized states is made.

The experience of transition economies of East Asia and some Eastern European countries of transition is considered, which clearly shows that where there are consistent market-economic and socio-political reforms, forces for economic development are established after a short transition crisis. Estonia, the Czech Republic, Slovenia, as well as Hungary and Poland are eloquent examples of this.

Proposed measures for the fair distribution of land resources and profits from the use of the country's wealth, its subsoil among all sections of the population, state control and lawful regulation of the tax and income system, as well as the pro-

Пьохов В. М., Шевчук В. В., 2019 gressive resolution of issues to prevent and combat both poverty and corruption.

Key words: poverty, corruption, elite corruption, mafia, democracy, living standards, living wage.

Постанова проблеми. За всі роки незалежності життя майже всіх українців, за винятком наближених до влади, із кожним роком стає все гірше та гірше, а «слуги народу» все частіше і частіше потрапляють у список найбагатших людей світу за версією Forbes. Водночас понад 70\% населення живе за межею бідності, а на порозі голодної смерті доживає 25\% українців. Усе це свідчить про те, що всі державні органи та їх очільники не виконували і не виконують своїх прямих функціональних обов'язків [1, с. 22]. Це дуже небезпечна ситуація.

Аналіз останніх досліджень. Питання виникнення і боротьби з бідністю та всебічного зниження життєвого рівня населення досліджували такі науковці, як: О.І. Амоша, В.П. Антонюк, І.М. Бабака, Н.П. Борецька, Г.Л. Вербицька, Н.С. Власенко, О.А. Грішнова, Е.М. Лібанова, В.М. Новіков, І.В. Качалова, Л.С. Шевченко; боротьбу 3 корупцією досліджували Л.В. Багрій-Шахматов, Г.Д. Божок, Т.В. Ільєнок, І.Ю. Карпінський, М.В. Колеснікова, С.Ж. Лазаренко, М.І. Мельник, Е.С. Молдован, $\epsilon$. В. Невмержицький та інші.

Не применшуючи значення робіт вітчизняних науковців, варто зазначити, що ці проблеми не тільки досі невирішені, а навпаки, заглибилися і вимагають нової, чіткої систематизації всієї антисоціальної піраміди знищення народу України - геноциду XXI століття, поступового вирішення питань зниження рівня корупції і бідності, а також чесного розподілу земних ресурсів і прибутків від користування багатствами країни, їі надрами між усіма верствами населення, державного контролю і правомірного регулювання системи податків та доходів.

Мета статті полягає в з'ясуванні причин виникнення бідності та її взаємозв'язок з корупцією в Україні та вирішення проблем зниження корупції і підвищення життєвого рівня зубожілого народу.

Виклад основного матеріалу дослідження. У прийнятому 5 жовтня 1995 р. Законі України «Про боротьбу 3 корупцією» (ст. 1) сформульовано: «Під корупцією розуміється діяльність осіб, уповноважених на виконання функцій держави, спрямована на протиправне використання наданих їм повноважень для одержання матеріальних благ, послуг, пільг або інших переваг» [2].

В умовах реалізації так званих «комплексних реформ», тривалої військової агресії на Донбасі, системної кризи, повсюдної бідності та тотальної корупції необхідно: визначити поняття, зародження, види, рівні, динаміку корупції та бідності; дослідити сутність корупції та її вплив на бідність і як ці деструк- 
тивні явища підривають основу демократії України; здійснити порівняльний аналіз з деякими країнами Євросоюзу, іншими цивілізованими державами та виробити класифікацію заходів із запобігання і протидії як бідності, так і корупції; на основі міжнародного досвіду запропонувати президенту i його команді принципи сучасної демократії та нової державної політики задля ефективної боротьби з елітною корупцією і покращення якості життя звичайних українців.

Як сказав Джейсон Гікел: «Випадки корупції зафіксовані істориками ще з моменту створення держави. Із розвитком людства еволюціонувало й ставлення до корупції від звичайної норми у первісному суспільстві до загрози конституційним правам і свободам громадян, правопорядку, чесності та соціальної справедливості. Корупція - це зловживання державною владою задля приватної вигоди» [3].

Корупція зачіпає всіх, оскільки вона паралізує економічний розвиток всієї країни і поглиблює бідність та безробіття. А бідність і безробіття породжують «депривацію - такий психічний стан, коли суб'єкт не має змоги задовольняти деякі свої основні (життєві) психічні потреби достатньою мірою впродовж тривалого часу» [4].

Нині більшість аналітиків закликають обчислювати депривації за стандартом ООН, керуючись не паритетом купівельної спроможності, а реальним курсом долара в країні [5].

Корупція $\epsilon$ головною причиною бідності людей в нашій «незалежній, правовій та демократичній» державі. Незалежна, правова та демократична країна існує насамперед для можновладців, а для простого люду залишаються тільки гасла, якими державно-владна олігархія, нахабно порушуючи норми моралі, демократії та Конституції, прикриває свої корупційні дії: постійно підвищуються тарифи на енергоносії; одночасно зростають ціни на соціальні продукти харчування і предмети першої необхідності; зменшуються чи повністю ліквідуються пільги чорнобильців, ветеранів МО, ДСНС, МBC та інвалідів.

І як прожити в центрі Європи, в Україні, місяць на 1497 грн (55 дол. США) мінімальної пенсії за встановленого нашими бюрократами заниженого прожиткового мінімуму в 1853 грн (І половина 2019 р.), який не відповідає світовим стандартам (з 2017 року) в 4200 грн (150 дол. США), що в 2,8 раза менше від визначеного ООН порогу бідності в 5,0 дол. США на день. Мінімальна заробітна плата 4173 грн (2019р.) теж не дотягує до світових стандартів прожиткового мінімуму [5].

3 цього приводу Олександр Вілкул зазначив, що лише підтримка промисловості та економіки забезпечить реальне, а не інфляційне зростання зарплат та пенсій. А нині навіть незначні підвищення виплат 3'їдаються зростанням цін і тарифів [6].

у 2020 році прожитковий мінімум на одну особу в розрахунку на місяць становитиме: 31 січня 2020 року - 2027 гривень, 31 липня - 2118 гривень, з 1 грудня - 2189 гривень [7]. За стандартами ООН, якщо людина витрачає на проживання та харчування менше 5 дол. на день, а на місяць менше 150 дол., вона живе за межею бідності. За даними Організації Об'єднаних Націй, за межею бідності проживає понад 80 відсотків українців [8]. Бідністю називають соціальне становище особи, яке характеризується відсутністю необхідних матеріальних засобів для того, щоб провадити «нор- мальне» життя, тобто реалізовувати конституційне право на достатній життєвий рівень для себе і своєї сім'ї.

Нині ситуація в країні гірша, ніж була три роки тому, і як сказала народний депутат України Наталія Королевська: «За підсумками роботи нашої країни за 1-й квартал 2019 року в нас кількість збиткових підприємств зросла, прибуток працюючих підприємств скоротився, іноземні інвестиції скоротилися в 20 разів, і це тільки підсумки трьох місяців. Країна знаходиться в колосальній економічній кризі. Тому зараз завдання -об'єднати професіоналів і вирішити всі проблеми, які $\epsilon »[9]$.

Норберт Нойгауз визначає: «Досвід країн з перехідною економікою Східної Азії та деяких східноєвропейських країн перехідного періоду чітко показує, що там, де послідовно здійснюються ринково-економічні і суспільно-політичні реформи після короткої перехідної кризи встановлюються сили для економічного розвитку. Естонія, Чехія, Словенія, а також Угорщина та Польща $\epsilon$ красномовними прикладами цьому...Чим більша пошесть корупції, тим більша проблема бідності, тим виразніша недорозвиненість і тим менше волі по-справжньому взятись і за реформи» [10].

Говорячи про поширеність корупції в нашій країні, необхідно визнати, що вона існує на всіх рівнях від району до міста, від області до центру, а коли риба гниє з голови, то корупційний «запах» відчувається на всій території України. Щодо динаміки та рівня корупції останні десятиліття ми займаємо «лідируючі позиції» у Європі.

Таблиця 1 Порівняльна таблиця середньої пенсії деяких країн світу у 2018 році [11]

\begin{tabular}{|l|c|}
\hline \multicolumn{1}{|c|}{ Країна } & Середня пенсія в доларах США \\
\hline Україна & 85 \\
\hline Білорусь & 150 \\
\hline Росія & 150 \\
\hline Китай & 150 \\
\hline Польща & 460 \\
\hline Іспанія & 1050 \\
\hline Франція & 1200 \\
\hline Німеччина & 1500 \\
\hline США & 1500 \\
\hline Ізраїль & 1500 \\
\hline Японія & 2000 \\
\hline
\end{tabular}

Бідність та зубожіння і як на це впливає корупція? На це питання дає відповідь Є.В. Невмержицький: «Світовий досвід переконує, що високий рівень життя населення і корупція - явища несумісні. Тому подолання бідності, зростання добробуту населення - найбільш надійний і результативний важіль подолання корупції» [12, с. 354].

У грудні (2017 р.) Україна не отримала від $€ C$ 600 мільйонів євро макрофінансової допомоги, бо серед іншого не забезпечила незалежності НАЗК і якісної перевірки декларацій. Саботаж керівництвом держави антикорупційної реформи вже настільки відвертий, що це очевидно не тільки нам, але й міжнародним партнерам України. Але чим яскравіше вони (депутати) проявляють себе, тим більше людей усвідомлюють, що ті, хто захищає власні інтереси, ніколи не діятиме 
в інтересах держави. Пам'ятайте про це тоді, коли від вашого вибору залежатиме доля країни [13].

Нині чітко зрозуміло, що корупція підриває віру суспільства у демократичність державних процесів, перешкоджає економічному розвиткові та загрожує належному і справедливому функціонуванню будь-якої країни [14].

Відповідно до Конституції Україна $є$ демократичною державою. Таким чином, політичні функції мають бути спрямовані на побудову демократичного суспільства. Проте Україна не просто пасе задніх у рейтингу демократичних держав світу. Як показує Індекс Демократії, протягом останніх десяти років Україна не наблизилася до кращих стандартів демократії, а навпаки, перейшла 3 категорії «демократія з недоліками» до так званих «гібридних режимів», в яких присутні ознаки авторитаризму [15].

Демократія у буквальному перекладі 3 грецької (demos - народ та cratos - влада) означає «влада народу». Найбільш вдалим визначенням $\epsilon$ загальновідоме формулювання 16-го президента США А. Лінкольна: демократія - «врядування іменем народу, обране народом і для народу».

Розглядаючи рівні демократії, треба визначити нижчий рівень - це рівень місцевого самоврядування, також $\epsilon$ регіональний, загальнодержавний та вищий - міжнародний. Стосовно форм демократії необхідно зазначити, що це такі форми суспільних відносин, за яких громадяни та організації залучаються до державотворення та державного управління, а також до місцевого самоврядування. Крім цих форм, у сучасних умовах використовується так звана електронна демократія (е-демократія, віртуальна демократія).

Українське законодавствовизначає електронну демократію як форму суспільних відносин, за якої громадяни та інститути громадянського суспільства залучаються до державотворення та державного управління, до місцевого самоврядування шляхом широкого застосування інформаційно-комунікаційних технологій у демократичних процесах з метою: посилити участь, ініціативність та залучення громадян на всіх рівнях до публічного життя; поліпшити прозорість процесу прийняття рішень, підзвітність демократичних інститутів; поліпшити реакцію суб'єктів владних повноважень на звернення громадян; сприяти публічним дискусіям та привертати увагу громадян до процесу прийняття рішень [16].

Для формування збалансованої державної політики без війни і корозії влади та ефективного проведення комплексу узгоджених системних заходів щодо захисту національних і міжнародних інтересів України у політичній, економічній, соціальній, екологічній, воєнній, науково-технічно-технологічній, інформаційній та в інших життєво важливих сферах вкрай необхідно виконати першочергові, пріоритетні дії, які набувають нині, в умовах критичної корупційної ситуації країни, першорядного значення: це - професійне кадрове забезпечення, фінансове, матеріально-технічне, інформаційне тощо; розробка основних напрямів і систем забезпечення національної безпеки; визначення стратегії і тактики розвитку правової, демократичної, справді соціальної держави.

Висновки. У нашій державі натепер, як не прикро констатувати, але працює не право і закон, а свавілля і беззаконня. Для того щоб була рівність усіх перед законом, поліпшилося життя народу, зародилася європейська демократія і запрацювала соціальна справедливість, в Україні необхідно: негайно припинити війну на Донбасі і звільнити всіх полонених; встановити соціальну справедливість, європейську демократію, законність і притягнути до кримінальної відповідальності винних за смерть на Майдані, в Одесі, на Донбасі і скрізь, де пролилася кров у боротьбі за мир, за життя, за Україну; провести перепис населення, скласти держгеокадастр усього земельного фонду для соціально справедливого розподілення між усім населенням; провести незалежний міжнародний аудит усіх підприємств, установ і організацій задля встановлення повної економічної ситуації та державного правомірного регулювання сучасної системи доходів; повернути в державну казну награбовані і незаконно виведені в офшори та інші держави гроші платників податків - кошти народу; конфіскувати незаконно нажите майно в дохід держави, де 6 воно не знаходилося; підтримувати науку і створити умови для розвитку IT і нано-технологій для отримання нових матеріалів і можливостей їх використання у різних галузях (медицині, ракетобудуванні, агропромисловому комплексі тощо); забезпечити надання послуг держслужбовцями з приводу видачі більшості дозвільних документів у цифровому форматі, що дасть можливість виключити прямий контакт і безпосередню залежність від хабарів; відновити і створити нові робочі місця як у промисловому секторі, так і сільському господарстві; покласти край порушенню екології в межах всієї України: незаконної вирубки лісів, незаконного видобутку бурштину, вугілля, які контрабандою вивозяться за кордон; перевести всі теплові станції (АЕС, ГЕС, ТЕЦ) та ДВС на поновлювані джерела енергії - водень, ККД якого в 2,5 раза більше і забруднення навколишнього середовища 0\%; створити умови для використання відновлюваної енергії сонця, вітру, води; надати оптимальну податкову навантаженість на малий і середній бізнес, що дасть можливість йому запрацювати на повну потужність і скоріше вивести із кризи нашу країну; удосконалити систему соціальних податків і внесків; підняти розмір заробітної плати і пенсії до європейського рівня; встановити плату за комунальні послуги в розмірі 10-15\% від мінімальної пенсії (європейський досвід); обчислювати депривації за стандартом ООН, керуючись не паритетом купівельної спроможності, а реальним курсом долара в країні.

Ця ситуація створила величезну можливість Президенту В.О. Зеленському ліквідувати політику подвійних стандартів разом з класом олігархів, який створив авторитарно-кланову систему і очолив політичну корупцію в країні. Це дасть змогу вирішити проблемні питання в політиці, економіці, екології, а це своєю чергою стане «запорукою справжнього забезпечення народовладдя в державі, розвитку територіальних громад за умови ефективної діяльності органів місцевого самоврядування, підвищення прозорості, відкритості та законності їх діяльності, мінімізації корупції та подолання перманентної соціально-економічної кризи» $[17$, с. 96] і в кінцевому підсумку все це має привести до політичної стабільності, економічного розвитку, європейської демократії і зростання довгоочікуваного добробуту громадян України. 


\section{Література}

1. Пьохов В.М., Шевчук В.В. Корупційне багатство та абсолютна бідність - загроза демократії України. Наука як рушійна сила ефективного розвитку держави : зб. наук. праць за матеріалами Міжнародної наук.-практ. конф. до Дня науки (17 травня 2019 р., м. Одеса). Одеса : ОІ МАУП, 2019. C. 22-30.

2. Про боротьбу з корупцією : Закон України від 5 жовтня 1995 p. URL: https://zakon.rada.gov.ua/laws/show/356/95-вp.

3. Джейсон Гікел. Перевернути міф про корупцію. URL: https://commons.com.ua/uk/perevernuti-mif-prokoruptsiyu/.

4. Варій М.Й. Психологія. URL: https: / /pidruchniki.com/ 19991130/psihologiya/psihologiya.

5. Економіка. URL: https://enovosty.com/uk/ ekonomika-ukr/full/2809-v-ukraini-zbilshivsya-rivenbidnosti-naselennya-na-shho-ne-vistachaye-groshej.

6. Вилкул А.Ю. Установленный в Украине прожиточный минимум в 2,5 раза ниже уровня бедности. URL: https: / / ukranews.com/news / 541001 -ustanovlennyy-vukrayne-prozhytochnyy-mynymum-v-25-raza-nyzhe-urovnyabednosty-vylkul.

7. Бюджет 2020 Україна - текст проєкту бюджету на 2020 рік. URL: https: / /24tv.ua/opublikuvali_tekst_proyektu_ byudzhetu_na_2020_rik_osnovni_tsifri_n1206081.

8. 00Н: $80 \%$ украинцев живёт за чертой бедности. URL: https://news.finance.ua/ru/news/-/351307/oon-80ukraintsev-zhivet-za-chertoj-bednosti.

9. Народный депутат Украины Наталья Королевская о ценовой политике на газ. URL: https://www.youtube.com/ watch? $=$ =Ns18vaNlbQ.

10. Норберт Нойгауз. Корупція - причина бідності і тривалої недорозвинутості. URL: http: / хіс.com.ua/z-zhyttja/ 21-problema/261-korupcija-prychyna-bidnosti-i-tryvalojinedorozvynutosti.

11. На яку пенсію живуть пенсіонери у різних країнах світу. URL: https://shepvisnyk.com.ua/na-yaku-pensiyuzhy-vut-pensionery-u-rizny-h-krayinah-svitu/.
12. Невмержицький Є.В. Корупція в Україні: причини, наслідки, механізм протидії : монографія. Київ : КНТ, 2008. $368 \mathrm{C}$.

13. Як Україна «пожертвувала» 600 мільйонами євро за безкарність корупціонерів. URL: https://24tv.ua/ yak_ukrayina_pozhertvuvala_600_milyonami_yevro_za_ bezkarnist_koputsioneriv_n902768.

14. Корупція та іï вплив на розвиток українського суспільства. URL: https://naukajournal.org/index.php/ naukajournal/article/view/467/645.

15. Як саботаж боротьби з корупцією штовхає нас до авторитаризму. URL: https://24tv.ua/yak_sabotazh_ borotbi_z_koruptsiyeyu_shtovhaye_nas_do_avtoritarizmu_ n1013315.

16. Концепція розвитку електронної демократії в Україні: схвалено Розпорядженням Кабінету Міністрів України від 8 листопада 2017 р. № 797-p. URL: https://zakon.rada.gov.ua/laws/show/797-2017-\%D1\%80.

17. Пьохов В.М., Шевчук В.В. Органи місцевого самоврядування: корупція та шляхи їі запобігання. Перспективні напрями вітчизняної науки : збірник наукових праць за матеріалами Міжвузівської наук.-практ. конф. до Дня науки (17 травня, 2018 р., м. Одеса), присвяченої 20-річчю Одеського інституту МАУП. Одеса : ОІ МАУП, 2018. C. 89-98.

Пьохов В. М., кандидат юридичних наук, професор, завідувач кафедри правових дисциплін Одеського інституту Міжрегіональної Академії управління персоналом

Шевчук В. В., старший викладач кафедри конституційного та міжнародного права

одеського державного університету внутрішніх справ 